\title{
Effects of Alloying Element and Heat Treatment on Properties of $\mathrm{Cu}$-Ti Alloys
}

\author{
Han-Gil Suk ${ }^{\mathrm{a}}$, Hyun Seon Hong ${ }^{\mathrm{b}^{*}}$ \\ aDepartment of Materials and Metallurgical Eng., Kangwon National University, \\ Samcheok 245-711, Korea \\ bPlant Engineering Center, Institute for Advanced Engineering (IAE), Yongin 449-863, Korea
}

(Received October 6, 2009 ; revised October 28, 2009 ; accepted October 30, 2009)

\begin{abstract}
$\mathrm{Cu}-\mathrm{Ti}$ alloys with titanium in the range of 0.5-6.0 wt\% were developed to evaluate the effect of the titanium content and heat treatment on microstructure, hardness, and electrical conductivity. The hardness of the Tiadded copper alloys generally increased with the increase in titanium content and hardening was effective up to the $2.5 \mathrm{wt} \%$-Ti addition. Microstructural examination showed that the second phase of $\mathrm{Cu}_{4} \mathrm{Ti}$ started to precipitate out from the $3.0 \mathrm{wt} \%$ Ti-addition, and the precipitate size and volume fraction increased with further Ti addition. Aging of the present $\mathrm{Cu}$-Ti alloys at $450^{\circ} \mathrm{C}$ for $1 \mathrm{~h}$ increased the hardness; however, the further aging up to $10 \mathrm{~h}$ did not much change the hardness. In the present study, it was inferred that in optimal $\mathrm{Ti}$ addition and aging condition $\mathrm{Cu}-\mathrm{Ti}$ alloy could have the hardness and electrical conductivity values which are comparable to those of commercial $\mathrm{Cu}-\mathrm{Be}$ alloy.
\end{abstract}

Keywords: Copper alloys, Metals and alloys, Hardness, Electrical properties

\section{Introduction}

Copper alloys with beryllium (Cu-Be alloys) have attracted considerable interest due to their good combination of high strength and high electrical conductivity. $\mathrm{Cu}-\mathrm{Be}$ alloys are currently used in spring, wire, load cells and other parts that must retain their shapes. They are also used in current contacts for batteries and electrical interconnectors because of its electrical conductivity. Many studies have been done on age hardenable $\mathrm{Cu}-\mathrm{Be}$ alloys, which have found their application in developing high strength springs and interconnectors. However, $\mathrm{Cu}-\mathrm{Be}$ alloys are expensive and health hazardous and thus $\mathrm{Cu}-\mathrm{Ti}$ alloys are considered as a prominent alternative. The mechanical properties of $\mathrm{Cu}-\mathrm{Ti}$ alloys are comparable to commercially developed $\mathrm{Cu}-\mathrm{Be}$ alloys ${ }^{1-6)}$.

In the case of most precipitation hardenable alloys, a high strength is attained if the alloys are properly

*Corresponding author. E-mail : hshong@iae.re.kr solution-treated and aged. It has been known that if $\mathrm{Cu}-\mathrm{Ti}$ alloys were optimally heat-treated, the ultimate tensile strength exceeding $1000 \mathrm{MPa}$ could be attained. However, systematic research on $\mathrm{Cu}-\mathrm{Ti}$ alloys has not yet been carried out and scare literature exists regarding multi-alloying element systems and continuously cast alloys ${ }^{7-10}$.

The aim of the present study is to give a contribution to the understanding of the effects of titanium content and aging treatment on properties of $\mathrm{Cu}-\mathrm{Ti}$ binary alloys and to provide fundamental data for designing of multi-alloying element systems such as $\mathrm{Cu}-\mathrm{Ti}-x-y$ where $x$ and $y$ could be $\mathrm{Ni}, \mathrm{Co}, \mathrm{Fe}$ and so on, which will be presented in forthcoming companion paper. The present investigation includes: (a) the effect of the titanium content on hardness and microstructure; (b) the influence of heat treatment on hardness and electrical conductivity.

\section{Experimental}

Cu-Ti binary alloys were prepared by the arc 
Table 1. Chemical composition of the specimens (wt\%)

\begin{tabular}{|c|c|}
\hline Specimen No. & Nominal Composition \\
\hline No.1 & $\mathrm{Cu}-0 \mathrm{Ti}$ \\
\hline No. 2 & $\mathrm{Cu}-0.5 \mathrm{Ti}$ \\
\hline No.3 & $\mathrm{Cu}-1.5 \mathrm{Ti}$ \\
\hline No.4 & $\mathrm{Cu}-2.5 \mathrm{Ti}$ \\
\hline No.5 & $\mathrm{Cu}-3.0 \mathrm{Ti}$ \\
\hline No.6 & $\mathrm{Cu}-3.5 \mathrm{Ti}$ \\
\hline No.7 & $\mathrm{Cu}-4.0 \mathrm{Ti}$ \\
\hline No.8 & $\mathrm{Cu}-5.0 \mathrm{Ti}$ \\
\hline No.9 & $\mathrm{Cu}-6.0 \mathrm{Ti}$ \\
\hline
\end{tabular}

melting. The ingot melting was carried out under argon gas atmosphere. The chemical composition of the ingot is listed on Table 1 . The titanium content varied from zero to $6 \mathrm{wt} \%$. After the ingot melting, the solid solution treatment of the samples was conducted at $920^{\circ} \mathrm{C}$ for $3 \mathrm{~h}$ and the aging treatments for the alloys were performed at $450^{\circ} \mathrm{C}$ for $1 \mathrm{~h}, 5 \mathrm{~h}$ and $10 \mathrm{~h}$.

The metallographic samples of the titanium copper alloys were first mechanically wet ground using a \#1200 SiC grit paper, then polished with $3 \mu \mathrm{m}$ diameter $\mathrm{Al}_{2} \mathrm{O}_{3}$ powder, followed by etching in a mixture of nitric acid and hydrogen peroxide $(5 \mathrm{ml}$ $\mathrm{HNO}_{3}+15 \mathrm{ml} \mathrm{H} \mathrm{H}_{2}$ at $25^{\circ} \mathrm{C}$ ). After etching, the specimens were cleaned with distilled water, and then dried in air. Subsequently, the specimen was examined in a scanning electron microscope (SEM).

The samples for hardness measurements were wet ground using \#1200 SiC grit paper, then tested on the Rockwell hardness F scale. Electrical conductivity was measured according to ASTME 1004 with a FISCHER's SMP-10 instrument.

\section{Results and Discussion}

Fig. 1 represents the variation of hardness of $\mathrm{Cu}-$ $x \mathrm{Ti}$ alloys as a function of titanium content. The hardness was measured by Rockwell $F$ scale on the as-cast samples. As the $\mathrm{Ti}$ content increased from $0.5 \mathrm{wt} \%$ to $2.5 \mathrm{wt} \%$, the hardness of the alloy increased from $29 \mathrm{H}_{\mathrm{f}}$ to $91 \mathrm{H}_{\mathrm{f}}$. Further addition of the $\mathrm{Ti}$ content up to $6 \mathrm{wt} \%$ showed relatively slight increase in hardness. The value increased only by 25 $\mathrm{H}_{\mathrm{f}}$. Fig. 2 shows XRD patterns of the $\mathrm{Cu}-x \mathrm{Ti}$ alloys as a function of titanium concentration. Up to the $2.5 \mathrm{wt} \%$ Ti-addition, the structure of the alloy remained as the fcc copper single phase, however, the second phase of $\mathrm{Cu}_{4} \mathrm{Ti}$ started to precipitate out from the

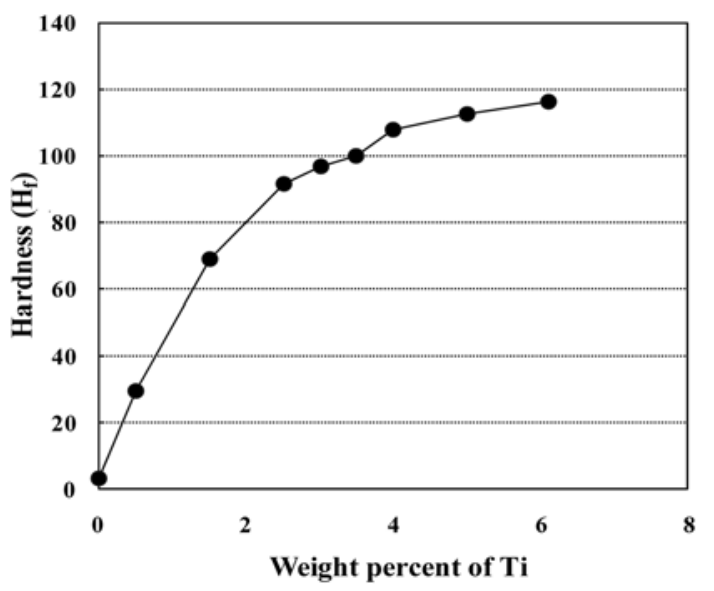

Fig. 1. Changes of hardness of Cu-XTi alloys in as-cast condition.

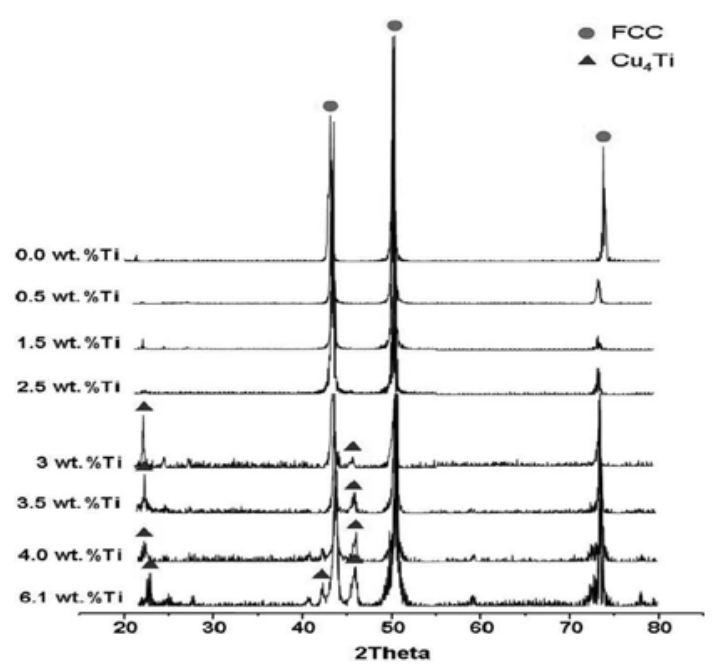

Fig. 2. XRD patterns of Cu-XTi alloys in as-cast condition.

$3.0 \mathrm{wt} \%$ Ti-addition. This precipitation might reduce the effect of Ti-addition on hardness increase.

Although the phase diagram of the copper-titanium system has been studied, the solubility of titanium in copper at room temperature has not yet been clarified $^{11,12)}$. However, it can be estimated by using the terminal solubility equation, $\mathrm{C}=\mathrm{C}_{0} \exp (-\Delta \mathrm{H} / \mathrm{RT})$. The solubilities of silicon at $885^{\circ} \mathrm{C}$ and at $500^{\circ} \mathrm{C}$ are reported to be $8 \mathrm{wt} \%$ and $0.8 \mathrm{wt} \%$, respectively. From these data the $\Delta \mathrm{H}$ and the $\mathrm{C}_{0}$ values can be determined, and the solubility of titanium at room temperature is calculated to be about $1.2 \times 10^{-5} \mathrm{wt} \%$. Therefore, the lowest titanium content $(0.5 \mathrm{wt} \%)$ used in this study is considered to be far above the solubility limit of titanium at room temperature. Accordingly, it is considered that this supersaturated titanium could induce the increase in strength upon aging through titanium precipitates.

Fig. 3 shows the microstructural change of $\mathrm{Cu}-\mathrm{Ti}$ 


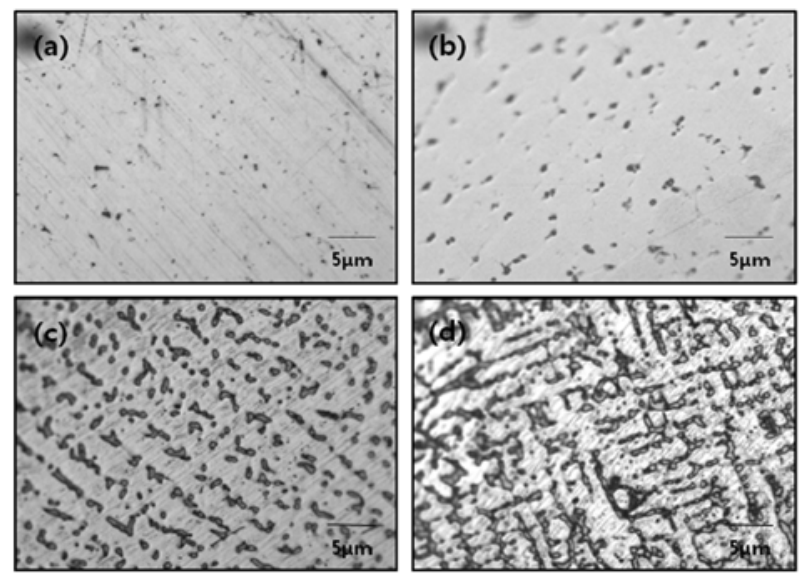

Fig. 3. Microstructural changes with varying Ti concentration; (a) $0.1 \mathrm{wt} \% \mathrm{Ti}$, (b) $1.0 \mathrm{wt} \% \mathrm{Ti}$, (c) $3.0 \mathrm{wt} \% \mathrm{Ti}$, (d) $4.0 \mathrm{wt} \% \mathrm{Ti}$.

alloys as a function of $\mathrm{Ti}$ content. As $\mathrm{Ti}$ content increased, the number of precipitates and the volume fraction of precipitates increased. It can be seen in the $3.0 \mathrm{wt} \% \mathrm{Ti}$ sample that precipitates began to merge so the size of precipitates increased. It is thought that the precipitate $\mathrm{Cu}_{4} \mathrm{Ti}$ formed, which was revealed from XRD examination, and merged from the $3.0 \mathrm{wt} \%$ Ti-addition thereby reducing the precipitate hardening effect.

In order to investigate the influence of aging on hardness enhancement, the as-cast samples were solid solution treated at $920^{\circ} \mathrm{C}$ for $3 \mathrm{~h}$ and then aged at $450^{\circ} \mathrm{C}$ for $1 \mathrm{~h}, 5 \mathrm{~h}$ and $10 \mathrm{~h}$. The solid solution and aging temperatures were selected according the $\mathrm{Cu}-\mathrm{Ti}$ phase diagram and literatures $\mathrm{s}^{1-3,11,12)}$ and the aging time was varied in order to see its influence. The aging experiment was conducted only on $1.5 \mathrm{wt} \%$ and $2.5 \mathrm{wt} \% \mathrm{Ti}$ samples which showed good hardness results. Fig. 4 exhibits the relationship between hardness and aging time for the $\mathrm{Cu}-2.5 \mathrm{wt} \%$ $\mathrm{Ti}$ and $\mathrm{Cu}-1.5 \mathrm{wt} \% \mathrm{Ti}$ alloys. In the case of the $\mathrm{Cu}-$ $2.5 \mathrm{wt} \% \mathrm{Ti}$ alloy, the hardness increased from $78 \mathrm{H}_{\mathrm{f}}$

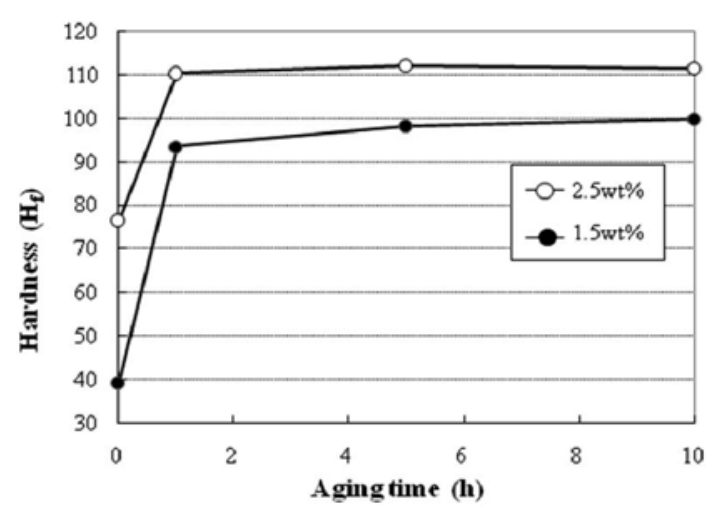

Fig. 4. Changes of hardness of $\mathrm{Cu}-1.5 \mathrm{wt} \% \mathrm{Ti}$ and $\mathrm{Cu}-$ $2.5 \mathrm{wt} \% \mathrm{Ti}$ alloys as a function of aging time.

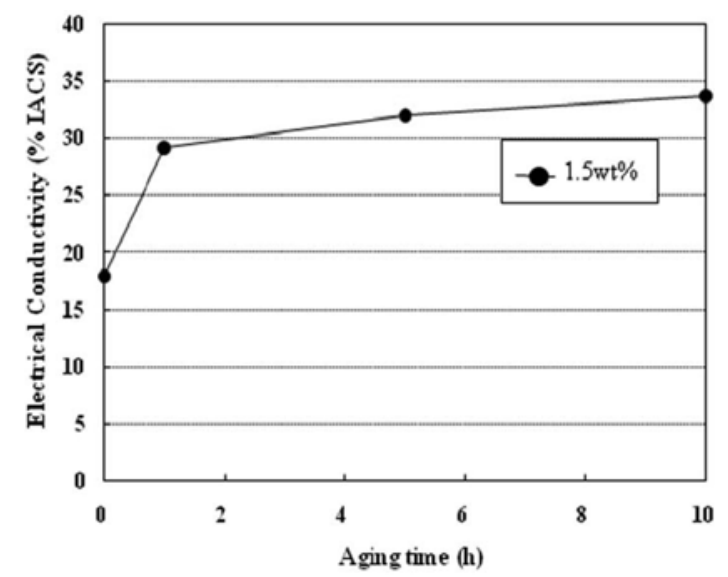

Fig. 5. Changes of electrical conductivity of $\mathrm{Cu}$ $1.5 \mathrm{wt} \% \mathrm{Ti}$ alloy as a function of aging time.

to $110 \mathrm{H}_{\mathrm{f}}$ after the 1-h aging. Further aging to $5 \mathrm{~h}$ slightly increased the hardness to $112 \mathrm{H}_{\mathrm{f}}$. It is to be noted that the hardness value of $112 \mathrm{H}_{\mathrm{f}}$ is comparable to that of commercial $\mathrm{Cu}-\mathrm{Be}$ alloy, 119 $\mathrm{H}_{\mathrm{f}}$. The aging for $10 \mathrm{~h}$ did not much change the hardness. The Cu-1.5 wt\% Ti alloy showed the similar results. The hardness increased for the first 1 $\mathrm{h}$ but the hardness remained the same up to the $10-\mathrm{h}$ aging.

In order to be an alternative for $\mathrm{Cu}-\mathrm{Be}$ alloys, $\mathrm{Cu}-$ Ti alloys should have good electrical conductivity. Fig. 5 shows the changes of electrical conductivity of the $\mathrm{Cu}-1.5 \mathrm{wt} \% \mathrm{Ti}$ alloy as a function of aging time. The electrical conductivity of the solid solution treated specimen was $18 \% \mathrm{IACS}$. After aging at $450^{\circ} \mathrm{C}$ for 1,5 and $10 \mathrm{~h}$, the electrical conductivity increased to $29 \% \mathrm{IACS}, 32 \% \mathrm{IACS}$ and $34 \% \mathrm{IACS}$, respectively. At this aging temperature, the electrical conductivity increased with the aging time. It is to be noted that the electrical conductivity value of $34 \% \mathrm{IACS}$ is comparable to those of $\mathrm{Cu}-\mathrm{Be}$ alloys, 20-50\%IACS.

\section{Conclusions}

For the $\mathrm{Cu}-\mathrm{Ti}$ alloys with titanium in the range of $0.5-2.5 \mathrm{wt} \%$, the addition of titanium was effective for producing age-hardenable alloys. The hardness of the $\mathrm{Cu}-2.5 \mathrm{wt} \% \mathrm{Ti}$ alloy was almost three times higher than that of $\mathrm{Cu}-0.5 \mathrm{wt} \% \mathrm{Ti}$ alloy in the as-cast condition. Aging of the Cu-2.5 wt\%Ti alloy at $450^{\circ} \mathrm{C}$ for $5 \mathrm{~h}$ increased the hardness value to $112 \mathrm{H}_{\mathrm{f}}$, which is comparable to the hardness of commercial $\mathrm{Cu}-\mathrm{Be}$ alloy. In the present study, the aging longer than $5 \mathrm{~h}$ did not affect the hardness enhancement. In order to design the multi-alloying element systems as 
substitutes for $\mathrm{Cu}-\mathrm{Be}$ alloys, the $\mathrm{Cu}-\mathrm{Ti}$ binary alloy with titanium content less than $2.5 \mathrm{wt} \%$ could be used with a proper heat treatment.

\section{Acknowledgment}

This paper was supported by the Campus Research Fund, Kangwon National University, 2008.

\section{References}

1. A. A. Hameda, L. J. Blaz, Mater. Eng., A254 (1998) 83.

2. I. S. Batra, A. Laik, G. B. Kale, G. K. Dey, U. D. Kulkarni, Mater. Sci. Eng., A 402 (2005) 118.

3. S. Nagarjuna, Bull. Mater. Sci., 27 (2004) 69.

4. W. A. Soffa, D. E. Laughlin, Prog. Mater. Sci., 49
(2004) 347.

5. I. S. Batra, G. K. Dey, U. D. Kulkarni, S. Banerjee, Mater. Sci. Eng., A (2003) 360.

6. Y. J. Oh, J. W. Ahn, J. G. Ahn, M. S. Lee, J. Kor. Inst. Surf. Eng., 35 (2002) 158.

7. S. Nagarjuna, M. Srinivas, K. Balasubramanian, D. S. Sarma, Acta Mater., 44 (1996) 2285.

8. S. Nagarjuna, K. K. Sharma, I. Sudhakar, D. S. Sarma, Mater. Sci. Eng., A 313 (2001) 251.

9. S. Nagarjuna, M. Srinivas, Mater. Sci. Eng., A 335 (2002) 89.

10. R. Markandeya, S. Nagarjuna, D. S. Sarma, Mater. Sci. Eng., A 404 (2005) 305.

11. T. B. Massalski, Binary Alloy Phase Diagrams, 2nd ed., ASM, Ohio, 1990.

12. R. P. Elliott, Constitution of Binary Alloys, McGrawHill, New York, 1965. 